87965-88-6; $\mathrm{NaL}_{\mathrm{P}}, 113779-90-1 ; \mathrm{NaL}_{\mathrm{Bu}}, 113779-91-2$; $\mathrm{NaL}{ }^{*}{ }_{\mathrm{OE}}$, 106333-06-6; $\mathrm{Na}\left[\left(\mathrm{C}_{5} \mathrm{H}_{5}\right) \mathrm{Co}\left\{\mathrm{P}(\mathrm{O})(\mathrm{OMe})_{2}\right\}(\mathrm{CN})_{2}\right], 113779-75-2 ;$ $\mathrm{Na}_{3}\left[\mathrm{Co}(\mathrm{CN})_{6}\right], 14039-23-7 ;\left[\mathrm{Cu}\left(\mathrm{CH}_{3} \mathrm{CN}\right)_{4}\right] \mathrm{PF}_{6}, 64443-05-6 ; \mathrm{CuSO}_{4}$, 17599-81-4; $\mathrm{C}_{2} \mathrm{H}_{4}, 74-85-1 ; \mathrm{Cu}, 7440-50-8$; methylphosphonous acid monomethyl ester, 14402-47-2; ethylphosphonous acid monomethyl ester, 27852-48-8; phenylphosphonous acid monomethyl ester, 63581-54-4; methylphosphonous acid monoisobutyl ester, 27852-51-3.

Supplementary Material Available: A listing of structure factor amplitudes (19 pages). Ordering information is given on any current masthead page.

\title{
Reactivity and Mechanlsm in Oxidative Addition to Palladium(II) and Reductive Ellmination from Palladium(IV) and an Estimate of the Palladium-Methyl Bond Energy
}

\author{
Peter K. Byers, ${ }^{1 a}$ Allan J. Canty, ${ }^{10}$ Margarita Crespo, ${ }^{1 \mathrm{~b}}$ Richard J. Puddephatt, ${ }^{* 1 \mathrm{~b}}$ and \\ John D. Scott ${ }^{10}$ \\ Chemistry Department, University of Tasmania, Hobart, Tasmania, Australla 7001, Department of Chemistry, \\ University of Western Ontario, London, Ontario Canada N6A 5B7, and 3M Canada InC., C.P./Box 5757, \\ London, Ontario, Canada N6A 4T1
}

Recelved November 13, 1987

\begin{abstract}
Oxidative addition of $\mathrm{MeI}$ to $\left[\mathrm{PdMe}_{2}(\mathrm{bpy})\right]$ (bpy $=2,2^{\prime}$-bipyridine) occurs by the $\mathrm{S}_{\mathrm{N}} 2$ mechanism. Evidence includes the observation of second-order kinetics in acetone solvent, with a large negative value for the entropy of activation, and the observation of a cationic species, $\left[\mathrm{PdMe}_{3}(\mathrm{bpy})\left(\mathrm{CD}_{3} \mathrm{CN}\right)\right]^{+} \mathrm{I}^{-}$, in $\mathrm{CD}_{3} \mathrm{CN}$ solvent. The reaction occurs more slowly than the analogous reaction of $\left[\mathrm{PtMe}_{2}(\mathrm{bpy})\right]$, but the same mechanism operates. Reductive elimination from [PdIMe $3(\mathrm{bpy})]$ to give ethane and [PdMMe(bpy)] follows good first-order kinetics, occurs more rapidly in polar solvents, and is strongly retarded by added iodide. These observations are interpreted in terms of a mechanism that involves preliminary ionization of iodide followed by reductive elimination from the cation $\left[\mathrm{PdMe}_{3}(\mathrm{bpy})\right]^{+}$. Studies by differential scanning calorimetry allow an estimate of the $\mathrm{Pd}-\mathrm{C}$ bond energy of $\sim 130 \mathrm{~kJ} \mathrm{~mol}^{-1}$ to be obtained, and this value is considerably higher than the activation energy for reductive elimination of ethane from [PdIMe $\left.e_{3}(\mathrm{bpy})\right]$ : The reductive elimination step is therefore concerted, and possible mechanisms, which may involve direct $\mathrm{C}-\mathrm{C}$ coupling or $\mathrm{C}-\mathrm{C}$ coupling after an agostic CHPd interaction, are discussed. This work is relevant to catalytic $\mathrm{C}-\mathrm{C}$ coupling reactions using palladium complex catalysts.
\end{abstract}

\section{Introduction}

The catalysis by palladium complexes of the coupling reaction of organometals $R M$ and organohalides $R^{\prime} X$ to give $\mathrm{RR}^{\prime}$ and $\mathrm{MX}$ is thought to be possible by oxidative addition-reductive elimination cycles involving either $\mathrm{Pd}(0)-\mathrm{Pd}(\mathrm{II})$ or $\mathrm{Pd}(\mathrm{II})-\mathrm{Pd}(\mathrm{IV})$ complexes. ${ }^{2}$ Models for the former catalytic cycle have been developed, ${ }^{3}$ but this has not been possible with $\mathrm{Pd}(\mathrm{II})-\mathrm{Pd}(\mathrm{IV})$ systems since the proposed organopalladium(IV) intermediates could not be detected by spectroscopic methods. ${ }^{4-7}$ The recent discovery of oxidative addition of methyl iodide to [PdMe ${ }_{2}$ (bpy)] (1) to give [PdIMe $e_{3}$ (bpy)] (2) which only slowly undergoes reductive elimination of ethane to give [PdIMe(bpy)] (3) (bpy $=2,2^{\prime}$-bipyridine) allows a study of the mechanisms of the reactions. ${ }^{8-10}$

(1) (a) University of Tasmania. (b) University of Western Ontario. (c) 3M Canada.

(2) For a recent review, see: Collman, J. P.; Hegedus, L. S.; Norton, J. R.; Finke, R. G. Principles and Applications of Organotransition Metal Chemistry; University Science Books: Mill Valley, CA, 1987.

(3) Ozawa, F.; Fujimori, M.; Yamamoto, T.; Yamamoto, A. Organometallics 1986, 5,2144 and references therein.

(4) Milstein, D.; Stille, J. K. J. Am. Chem. Soc. 1979, 101, 4981.

(5) Loar, M. K.; Stille, J. K. J. Am. Chem. Soc, 1981, 103, 4174

(6) Moravsky, A.; Stille, J. K. J. Am. Chem. Soc. 1981, 103, 4182.

(7) Kurosawa, H.; Emoto, M.; Urabe, A. J. Chem. Soc., Chem. Commun. 1984, 968.

(8) Byers, P. K.; Canty, A. J.; Skelton, B. W.; White, A. H. J. Chem. Soc, Chem. Commun. 1986, 1722.

\section{Results}

The Oxidative Addition Reaction. The reaction of [PdMe $e_{2}$ (bpy)] with $\mathrm{MeI}$ in $\mathrm{CD}_{3} \mathrm{CN}$ was monitored by ${ }^{1} \mathrm{H}$ NMR. The reagents were mixed at $-40^{\circ} \mathrm{C}$, and at this temperature resonances due to two products in $\sim 3: 1$ ratio were observed. Resonances due to the major product $\left[\mathrm{PdIMe}_{3}(\mathrm{bpy})\right]$ were at $\delta 1.79$ (PdMe trans to $\left.\mathrm{N}\right)$ and 1.20 (PdMe trans to I); the second product was assigned to the ionic $\left[\mathrm{PdMe}_{3}\left(\mathrm{CD}_{3} \mathrm{CN}\right)(\mathrm{bpy})\right]^{+} \mathrm{I}^{-}$with $\delta 1.61$ (PdMe trans to bpy) and 1.06 (PdMe trans to $\mathrm{CD}_{3} \mathrm{CN}$ ), related to isolated cations involving tripodal nitrogen donor ligands such as $\left[\mathrm{PdMe}_{3}\right.$ itris(pyridin-2-yl)methane)] $\mathrm{I}^{9}{ }^{9}$ Methyl group resonances for the cation broaden on warming, with coalescence at $\geqslant-5{ }^{\circ} \mathrm{C}$, but bpy resonances for the cation and all resonances for [PdIMe 3 (bpy)] remain sharp, consistent with intramolecular exchange (scrambling) of methyl environments in the cation; on recooling to low temperature the original spectrum is obtained, with identical integration. At higher temperatures $\left(\geqslant 15^{\circ} \mathrm{C}\right)$ bpy resonances for the neutral and cationic complexes are coalesced, and the bpy and methyl resonances are broad compared to the sharp, growing resonances for the product [PdIMe(bpy)], indicating exchange between $\left[\mathrm{PdMe}_{3}(\mathrm{bpy})\left(\mathrm{CD}_{3} \mathrm{CN}\right)\right]^{+} \mathrm{I}^{-}$

(9) Byers, P. K.; Canty, A. J.; Skelton, B. W.; White, A. H. J. Chem. Soc., Chem. Commun. 1987, 1093.

(10) Byers, P. K.; Canty, A. J.; Skelton, B. W.; White, A. H. J. Organomet. Chem. 1987, 336, C55. 
Table I. Second-Order Rate Constants for Oxidative Addition of $\mathrm{MeI}$ to $\left[\mathrm{MMe}_{2}(\mathrm{bpy})\right]$ in Acetone

\begin{tabular}{ccccc}
\hline $\mathrm{M}$ & $T,{ }^{\circ} \mathrm{C}$ & $k_{2}, \mathrm{~L} \mathrm{~mol} \mathrm{mo}^{-1} \mathrm{~s}^{-1}$ & $E_{\mathrm{g}}, \mathrm{kJ} \mathrm{mol}^{-1}$ & $\begin{array}{c}\Delta S^{*}\left(20^{\circ} \mathrm{C}\right), \\
\mathrm{J} \mathrm{K}^{-1} \mathrm{~mol}^{-1}\end{array}$ \\
\hline $\mathrm{Pd}$ & 3.0 & $1.75 \pm 0.05$ & & \\
$\mathrm{Pd}$ & 10.3 & $2.25 \pm 0.06$ & & \\
$\mathrm{Pd}$ & 20.0 & $3.23 \pm 0.08$ & & \\
$\mathrm{Pd}$ & 30.0 & $4.65 \pm 0.10$ & $25.3 \pm 0.6$ & $-148 \pm 2$ \\
$\mathrm{Pt}$ & -7.5 & $14 \pm 1$ & & \\
$\mathrm{Pt}$ & 3.6 & $22 \pm 1$ & & \\
$\mathrm{Pt}$ & 20 & $40 \pm 1$ & $24.9 \pm 0.1$ & $-129 \pm 1$
\end{tabular}

and $\left[\mathrm{PdIMe}_{3}(\mathrm{bpy})\right]$. Because of this apparent equilibrium between the cationic and neutral palladium(IV) products (the same mixture is obtained by dissolution of [PdIMe $\left.{ }_{3}(\mathrm{bpy})\right]$ in $\mathrm{CD}_{3} \mathrm{CN}$ ), the data do not prove that the cation is an intermediate in the formation of [PdIMe $\mathrm{P}_{3}$ (bpy)]. Similar results have been obtained for oxidative addition of $\mathrm{MeI}$ to $\left[\mathrm{PtMe}_{2}(\mathrm{bpy})\right]$, but in this case the cation $\left[\mathrm{PtMe}_{3}(\mathrm{bpy})\left(\mathrm{CD}_{3} \mathrm{CN}\right)\right]^{+}$was formed and then decayed to $\left[\mathrm{PtIMe}_{3}(\mathrm{bpy})\right]$, thus providing good evidence for the $\mathrm{S}_{\mathrm{N}} 2$ mechanism of oxidative addition. ${ }^{11}$ Exchange between the cationic and neutral platinum(IV) compounds was slow on the NMR time scale at temperatures up to $0^{\circ} \mathrm{C}$, above which temperature the cationic intermediate was no longer detectable. ${ }^{11}$

In a similar reaction, $\mathrm{CD}_{3} \mathrm{I}$ was added to $\left[\mathrm{PdMe}_{2}(\mathrm{bpy})\right]$ in acetone- $d_{6}$ solution at $-60^{\circ} \mathrm{C}$. At this temperature signals due to $\left[\mathrm{PdMe}_{2}(\mathrm{bpy})\right]$ and $\left[\mathrm{PdIMe}_{2}\left(\mathrm{CD}_{3}\right)(\mathrm{bpy})\right]$ were observed, but no ionic intermediate was detected. Resonances due to $\left[\mathrm{PdIMe}_{2}\left(\mathrm{CD}_{3}\right)(\mathrm{bpy})\right]$ were observed for both $\mathrm{Me}$ trans to bpy and Me trans to I in a 2:1 intensity ratio. Hence scrambling of $\mathrm{Me}$ and $\mathrm{CD}_{3}$ had already occurred. It is probable that the presumed ionic intermediate $\left[\mathrm{PdMe}_{2}\left(\mathrm{CD}_{3}\right)(\mathrm{bpy})\right]^{+} \mathrm{I}^{-}$undergoes $\mathrm{Me}$ for $\mathrm{CD}_{3}$ scrambling before rearrangement to the product. The analogous reaction with $\left[\mathrm{PtMe}_{2}(\mathrm{bpy})\right]$ gives trans oxidative addition only, and a slow intramolecular $\mathrm{Me}, \mathrm{CD}_{3}$ scrambling reaction occurs subsequently. ${ }^{11}$

The kinetics of the oxidative addition in acetone solution, using at least an 8-fold excess of MeI, were monitored by UV-visible spectrophotometry. The oxidative addition was sufficiently fast that the subsequent reductive elimination of ethane did not interfere significantly. Good first-order kinetics were followed, and the observed firstorder rate constants were directly proportional to the concentration of methyl iodide. Hence overall secondorder kinetics were followed, first order in each reagent. For comparison, the oxidative addition to $\left[\mathrm{PtMe}_{2}(\mathrm{bpy})\right]$ was also studied and the activation parameters for both reactions were determined (Table I). The second-order rate constants for reaction with [PdMe $\mathrm{Pdpy}_{2}$ ] and $\left[\mathrm{PtMe}_{2}(\mathrm{bpy})\right]$ at $20^{\circ} \mathrm{C}$ were $3.23 \pm 0.08$ and $40.0 \pm 0.1 \mathrm{~L}$ $\mathrm{mol}^{-1} \mathrm{~s}^{-1}$, respectively, and the corresponding activation parameters were $E_{\mathrm{a}}=25.3 \pm 0.6$ and $24.94 \pm 0.06 \mathrm{~kJ} \mathrm{~mol}^{-1}$, respectively, and $\Delta S^{*}\left(20^{\circ} \mathrm{C}\right)=-148 \pm 2$ and $-129.0 \pm 1.0$ $\mathrm{J} \mathrm{K}^{-1} \mathrm{~mol}^{-1}$, respectively. The platinum complex reacts over 10 times as fast as the palladium analogue largely due to a less unfavorable $\Delta S^{*}$ term. All of the kinetic data, especially the large negative $\Delta S^{*}$ values, strongly support the $\mathrm{S}_{\mathrm{N}} 2$ mechanism of oxidative addition in both cases. . $^{2,1-14}$ The reactivity correlates with the energy of a metal $\left(\mathrm{d}_{\pi}\right)$ to bipyridine $\left(\pi^{*}\right)$ charge-transfer transition in

(11) Crespo, M.; Puddephatt, R. J. Organometallics 1987, 6, 2548. Scott, J. D.; Puddephatt, R. J. Organometallics 1985, 4, 1221.

(12) Monaghan, P. K.; Puddephatt, R. J. J. Chem. Soc., Dalton Trans., in press.

(13) Chock, P. B.; Halpern, J. J. Am. Chem. Soc. 1966, 88, 3511.

(14) Jawad, J. K.; Puddephatt, R. J. J. Chem. Soc., Dalton Trans. 1977,1466 .

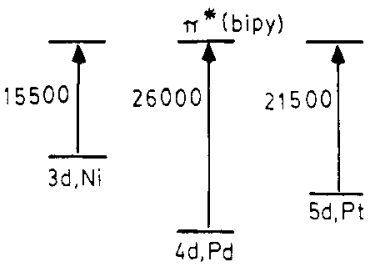

Figure 1. A qualitative MO energy level diagram for [ $\mathrm{MMe}_{2}$ (bpy)]. The diagram assumes that the $\pi^{*}$ levels of the $2,2^{\prime}$-bipyridine ligand are at the same energy when $\mathrm{M}=\mathrm{Ni}, \mathrm{Pd}$, or $\mathrm{Pt}$ and hence places the levels for the Ni 3d, $\mathrm{Pd} 4 \mathrm{~d}$, or Pt $5 \mathrm{~d}$ orbitals based on the energy of the respective metal to ligand chargetransfer transitions. The energies of the first MLCT bands are given in inverse centimeters.

the UV-visible spectrum which lies at $\sim 390 \mathrm{~nm}$ when M $=\mathrm{Pd}$ (a shoulder on the stronger $\pi-\pi^{*}$ band of coordinated bpy) and at $470 \mathrm{~nm}$ when $\mathrm{M}=\mathrm{Pt}$. The higher energy $\mathrm{d}$ orbitals on [PtMe $\left.{ }_{2}(\mathrm{bpy})\right]$ (see Figure 1) are more nucleophilic, and the complex reacts faster. A similar correlation within the platinum series $\left[\mathrm{PtR}_{2}(\mathrm{bpy})\right]$, with varying alkyl or aryl group $R$, has been noted previously. ${ }^{14}$

The Reductive Elimination Reaction. The reductive elimination of ethane from [PdIMe ${ }_{3}($ bpy)] could also be monitored readily by UV-visible spectrophotometry, using the increase in absorbance at $380 \mathrm{~nm}$ due to the palladium(II) product [PdIMe(bpy)]. Most work was carried out in acetone, in which the reductive elimination followed first-order kinetics. However, the mechanism was found to be fairly complex as described below. The observed rate constant at $20^{\circ} \mathrm{C}$ was $(6.24 \pm 0.03) \times 10^{-3} \mathrm{~s}^{-1}$, and this was decreased only slightly to $(3.65 \pm 0.03) \times 10^{-3} \mathrm{~s}^{-1}$ and $(3.90$ $\pm 0.02) \times 10^{-3} \mathrm{~s}^{-1}$ in the presence of excess MeI and bpy, respectively. However, in the presence of excess $\mathrm{NaI}$, the rate was greatly decreased to a limiting value of $(1.45 \pm$ $0.01) \times 10^{-4} \mathrm{~s}^{-1}$. This result strongly indicated that reductive elimination occurred to a major extent from the solvated cation $\left[\mathrm{PdMe}_{3}(\mathrm{bpy})\right]^{+}$, and so a detailed study of the rate of reductive elimination as a function of iodide concentration was made. The results were consistent with the kinetic scheme shown in eq 1-4 This scheme leads

$$
\begin{aligned}
& {\left[\mathrm{PdIMe}_{3}(\mathrm{bpy})\right] \stackrel{k_{1}}{\longrightarrow}[\mathrm{PdIMe}(\mathrm{bpy})]+\mathrm{C}_{2} \mathrm{H}_{6}} \\
& {\left[\mathrm{PdIMe}_{3}(\text { bpy })\right] \underset{k_{3}}{\stackrel{k_{2}}{\rightleftharpoons}}\left[\mathrm{PdMe}_{3}(\text { bpy })\right]^{+}+\mathrm{I}^{-}} \\
& {\left[\mathrm{PdMe}_{3}(\mathrm{bpy})\right]^{+} \stackrel{k_{4}}{\longrightarrow}[\mathrm{PdMe}(\mathrm{bpy})]^{+}+\mathrm{C}_{2} \mathrm{H}_{6}} \\
& {[\mathrm{PdMe}(\mathrm{bpy})]^{+}+\mathrm{I}^{-} \stackrel{\text { fast }}{\longrightarrow}[\mathrm{PdIMe}(\mathrm{bpy})]}
\end{aligned}
$$

to the kinetic expression

$$
-\frac{\mathrm{d}}{\mathrm{d} t}[2]=k_{1}[2]+k_{2} k_{4}[2] /\left(k_{3}\left[\mathrm{I}^{-}\right]+k_{4}\right)
$$

and gives the observed first-order rate constant $k_{\text {obsd }}=k_{1}$ $+k_{2} k_{4} /\left(k_{3}\left[\mathrm{I}^{-}\right]+k_{4}\right)$ or $1 /\left(k_{\text {obsd }}-k_{1}\right)=k_{3}\left[\mathrm{I}^{-}\right] / k_{2} k_{4}+1 / k_{2}$. An iterative treatment, Figure 2, was then used to give the values of $k_{1}=(1.45 \pm 0.01) \times 10^{-4} \mathrm{~s}^{-1}, k_{2}=(6.1 \pm 0.2) \times$ $10^{-3} \mathrm{~s}^{-1}$, and $k_{3} / k_{4}=(5.1 \pm 0.3) \times 10^{4} \mathrm{~L} \mathrm{~mol}^{-1}$. Hence, under the conditions of the kinetic experiments and in the absence of added iodide, $2.3 \%$ of the reductive elimination reaction occurs from [PdIMe $e_{3}$ (bpy)] and $97.7 \%$ from the cation $\left[\mathrm{PdMe}_{3}(\mathrm{bpy})\right]^{+}$or $\left[\mathrm{PdMe}_{3} \text { (bpy)(acetone) }\right]^{+}$. Stable cations related to the intermediate $[\mathrm{PdMe}(\mathrm{bpy})]^{+}$or $[\mathrm{PdMe}(\mathrm{bpy})(\text { acetone })]^{+}$have been reported recently, ${ }^{10}$ in particular $[\mathrm{PdMe}(\mathrm{bpy})(\mathrm{MeCN})]^{+}\left[\mathrm{BF}_{4}\right]^{-}$.

If this mechanism is correct, the rate would be expected to depend on the solvent polarity, since the ionic intermediate should be formed more readily in polar solvents. 
Table II. First-Order Rate Constants for Reductive Elimination from [PdIMe $($ bpy)]

\begin{tabular}{|c|c|c|c|c|c|}
\hline$T,{ }^{\circ} \mathrm{C}$ & {$\left[\mathrm{I}^{-}\right], \mathrm{M}$} & solvent & $k_{1}, \mathrm{~s}^{-1}$ & $E_{\mathrm{a}}, \mathrm{kJ} \mathrm{mol}^{-1}$ & $\Delta S^{*}\left(20^{\circ} \mathrm{C}\right), \mathrm{J} \mathrm{K}^{-1} \mathrm{~mol}^{-1}$ \\
\hline 4.0 & 0 & acetone & $(8.4 \pm 0.1) \times 10^{-4}$ & & \\
\hline 10.0 & 0 & acetone & $(1.35 \pm 0.1) \times 10^{-3}$ & & \\
\hline 20.0 & 0 & acetone & $(6.25 \pm 0.03) \times 10^{-3}$ & & \\
\hline 30.2 & 0 & acetone & $(7.8 \pm 0.1) \times 10^{-3}$ & $65 \pm 13$ & $-66 \pm 34$ \\
\hline 20.0 & $3.6 \times 10^{-2}$ & acetone & $(1.45 \pm 0.01) \times 10^{-4}$ & & \\
\hline 30.0 & $3.6 \times 10^{-2}$ & acetone & $(5.27 \pm 0.03) \times 10^{-4}$ & & \\
\hline 40.0 & $3.6 \times 10^{-2}$ & acetone & $(1.13 \pm 0.02) \times 10^{-3}$ & $78 \pm 11$ & $-53 \pm 25$ \\
\hline 20.0 & 0 & benzene & $(4.60 \pm 0.04) \times 10^{-4}$ & & \\
\hline 30.0 & 0 & benzene & $(8.82 \pm 0.06) \times 10^{-4}$ & & \\
\hline 20.0 & 0 & methanol & $(5.38 \pm 0.02) \times 10^{-3}$ & & \\
\hline 30.0 & 0 & methanol & $(1.33 \pm 0.02) \times 10^{-2}$ & & \\
\hline 20.0 & $3.6 \times 10^{-2}$ & methanol & $(1.95 \pm 0.02) \times 10^{-3}$ & & \\
\hline 30.0 & $3.6 \times 10^{-2}$ & methanol & $(3.68 \pm 0.02) \times 10^{-3}$ & & \\
\hline 40.0 & $3.6 \times 10^{-2}$ & methanol & $(5.47 \pm 0.06) \times 10^{-3}$ & $39 \pm 5$ & $-164 \pm 17$ \\
\hline
\end{tabular}

Table III. First-Order Rate Constants for Reductive Elimination of [PdIMe $\left(\right.$ bpy) in Acetone Solution at $20^{\circ} \mathrm{C}$ in the Presence of Iodide

\begin{tabular}{cccc}
\hline $10^{3}[\mathrm{NaI}], \mathrm{M}$ & $10^{4} k_{1}, \mathrm{~s}^{-1}$ & $10^{3}[\mathrm{NaI}], \mathrm{M}$ & $10^{4} k_{1}, \mathrm{~s}^{-1}$ \\
\hline 0 & 62.5 & 1.008 & 2.27 \\
0.103 & 5.66 & 1.20 & 2.09 \\
0.206 & 3.74 & 2.015 & 2.11 \\
0.412 & 3.10 & 2.67 & 1.89 \\
0.667 & 2.54 & 4.03 & 1.72
\end{tabular}

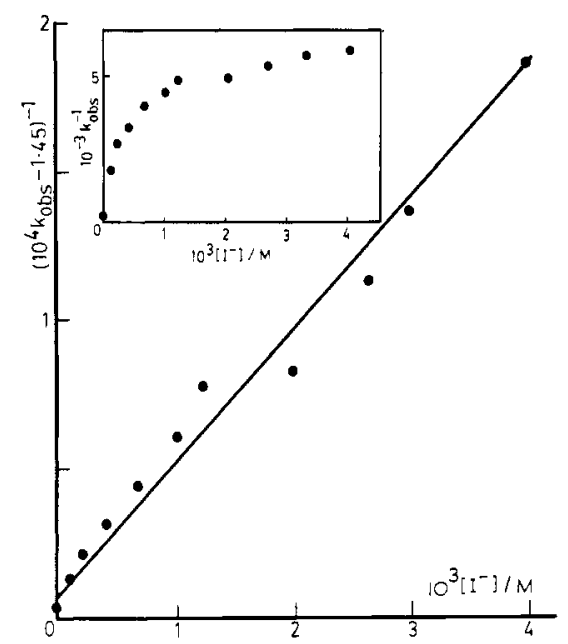

Figure 2. A graph of $\left(10^{4} k_{\text {obed }}-1.45\right)^{-1}$ vs concentration of iodide for the reductive elimination of ethane from [PdIMe $\left.\mathrm{P}_{3}(\mathrm{bpy})\right]$ in acetone at $20^{\circ} \mathrm{C}$, where $k_{\text {obad }} / \mathrm{s}^{-1}$ is the observed first-order rate constant for the reaction. The inset shows the corresponding plot of $\left(10^{3} k_{\text {obed }}\right)^{-1}$ vs $\left[\mathrm{I}^{-}\right]$which is clearly nonlinear but rises to a plateau value at high $\left[\mathrm{I}^{-}\right]$.

Observed first-order rate constants in the absence of added iodide at $30^{\circ} \mathrm{C}$ were found to be $(0.882 \pm 0.002) \times 10^{-3} \mathrm{~s}^{-1}$, $(7.8 \pm 0.1) \times 10^{-3} \mathrm{~s}^{-1}$, and $(13.4 \pm 0.5) \times 10^{-3} \mathrm{~s}^{-1}$ in benzene, acetone, and methanol, respectively. These data are fully consistent with the proposed mechanism, the rates being faster in the more polar solvents.

Interestingly, the limiting rate of reaction in methanol at $20^{\circ} \mathrm{C}$ in the presence of a large excess of iodide was $(1.95$ $\pm 0.01) \times 10^{-3} \mathrm{~s}^{-1}$ compared to the value $(1.45 \pm 0.01) \times$ $10^{-4} \mathrm{~s}^{-1}$ in acetone. This 13 -fold increase in rate in methanol over acetone for the reaction of eq 1 was surprising and suggested that a polar intermediate or transition state might be involved. A study of the activation parameters for the reductive elimination reaction was therefore undertaken. In the absence of added iodide the observed parameters with acetone solvent were $E_{\mathrm{a}}=65 \pm 13 \mathrm{~kJ}$ $\mathrm{mol}^{-1}$ and $\Delta S^{*}\left(20^{\circ} \mathrm{C}\right)=-66 \pm 34 \mathrm{~J} \mathrm{~K}^{-1} \mathrm{~mol}^{-1}$. The large standard deviations arise because of the sensitivity of the observed rate constant to trace impurities that retard the reaction and hence the difficulties in obtaining good re- productibility under these conditions. The negative value of $\Delta S^{*}$ is consistent with formation of a polar intermediate (eq 2) since much greater solvent ordering would occur for the ionic intermediate. Activation parameters were also determined for the reactions in the presence of a large excess of iodide, so that the parameters are those for the reaction of eq 1 . Values in acetone and methanol, respectively, were $E_{\mathrm{a}}=78 \pm 11$ and $39 \pm 5 \mathrm{~kJ} \mathrm{~mol}^{-1}$ and $\Delta S^{*}$ $=-53 \pm 25$ and $-164 \pm 17 \mathrm{~J} \mathrm{~K}^{-1} \mathrm{~mol}^{-1}$. Again these values strongly suggest a polar intermediate or transition state and are not consistent with a nonpolar concerted reductive elimination. A likely explanation of these data is that at least partial ionization of iodide occurs before reductive elimination of ethane. Thus, the precursor state to reductive elimination could be a polar species $\left[\mathrm{Me}_{3}(\mathrm{bpy})\right.$ $\left.\mathrm{Pd}^{\delta+} \ldots \mathrm{I}^{\delta-}\right]$, or it could be a tight ion pair $\left[\mathrm{Me}_{3}(\mathrm{bpy}) \mathrm{Pd}\right]^{+} \mathrm{I}^{-}$. In neither case would inhibition by iodide occur, but both species are highly polar and would cause the solvent ordering required by the negative $\Delta S^{\ddagger}$ values.

Thus although the kinetic studies indicate a two-term rate law, one retarded by free iodide and the other not, it is probable that ionization of the PdI bond is important in both cases and that reductive elimination from the cationic or partially cationic intermediate occurs relatively easily.

The complex $\left[\mathrm{PtIMe}_{3}(\mathrm{bpy})\right]$ is very stable and decomposes only at $\sim 270^{\circ} \mathrm{C}$ to give methane as the major product. Hence it is not possible to compare the mechanisms in this case. The complexes [PtIMe $\mathrm{L}_{2}$ ] $(\mathrm{L}=$ tertiary phosphine) undergo reductive elimination by a mechanism involving reversible phosphine dissociation followed by loss of ethane from the neutral five-coordinate species $\left[\mathrm{PtIMe} \mathrm{H}_{3} \mathrm{~L}\right]^{15}$ Thus it seems general that reductive elimination from $\mathrm{d}^{6}$ complexes is easier from intermediates with coordination number five. A rationalization of this observation has been given. ${ }^{15}$

The general observations above have been confirmed by monitoring the kinetics of the reductive elimination by ${ }^{1} \mathrm{H}$ NMR spectroscopy. These experiments were carried out by using $0.02 \mathrm{M}$ solutions of [PdIMe $\mathrm{Pdpy}_{3}$ ] in acetone- $d_{6}$, prepared in situ by reaction of [PdMe $\mathrm{Pdpy}_{2}$ ] with excess $\mathrm{MeI}$, at temperatures from 9 to $25^{\circ} \mathrm{C}$. Good first-order kinetics were followed, the rates were greater in the presence of water to increase the solvent polarity, and the rates were retarded in the presence of free iodide.

The Palladium-Carbon Bond Energy. The reductive elimination of ethane from [PdIMe $\left.e_{3}(\mathrm{bpy})\right]$ to give [PdIMe(bpy)] occurs very cleanly in the solid state, ${ }^{8}$ and the reaction has now been monitored by differential scanning calorimetry (DSC). A typical DSC scan is given

(15) Brown, M. P.; Puddephatt, R. J.; Upton, C. E. E. J. Chem. Soc., Dalton Trans. 1974, 2457. 


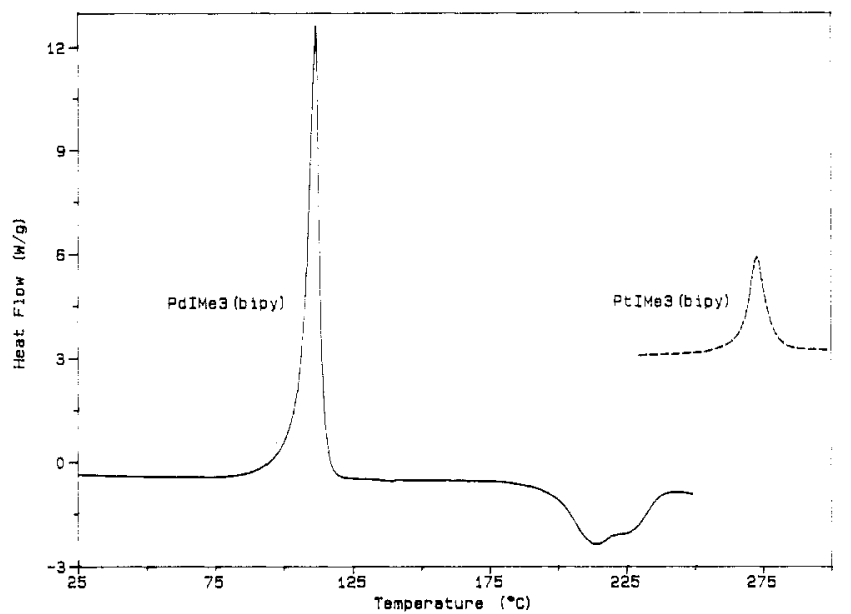

Figure 3. Differential scanning calorimetry for the decomposition of (a) $\left[\mathrm{PdIMe}_{3}(\mathrm{bpy})\right]$ and (b) $\left[\mathrm{PtIMe}_{3}\right.$ (bpy)].

in Figure 3. Decomposition began at $\sim 80^{\circ} \mathrm{C}$ and was complete at $\sim 120^{\circ} \mathrm{C}$, giving a very clean exotherm. Weight loss was calculated to be $6.9 \%$ and found to be 7.3 $\pm 0.2 \%$, and the product was confirmed to be pure [PdIMe(bpy)] by NMR. Further general decomposition occurred at $180-240^{\circ} \mathrm{C}$ (Figure 3). The integrated area of the exotherm centered at $\sim 110^{\circ} \mathrm{C}$ gave $\Delta H=-105 \pm$ $2 \mathrm{~kJ} \mathrm{~mol}^{-1}$. An approximation to the mean $\mathrm{Pd}-\mathrm{Me}$ bond energy can then be obtained if it is assumed that this enthalpy change corresponds only to formation of the $\mathrm{C}-\mathrm{C}$ bond of ethane ( $368 \mathrm{~kJ} \mathrm{~mol}^{-1}$ ) and loss of two $\mathrm{Pd}-\mathrm{Me}$ bonds. The nature of the approximations has been discussed elsewhere. ${ }^{16}$ Hence $D(\mathrm{PdMe})=1 / 2(368-105)=$ $131.5 \pm 6 \mathrm{~kJ} \mathrm{~mol}^{-1}$. This appears to be the first estimate of a $\mathrm{Pd}-\mathrm{C}$ bond energy. The $\mathrm{Pd}-\mathrm{C}$ bonds are reasonably strong and may be compared with a value of $D(\mathrm{PtMe})$ in $\left[\mathrm{PtIMe} \mathrm{P}_{3}\left(\mathrm{PMe}_{2} \mathrm{Ph}\right)_{2}\right.$ ] of $144 \mathrm{~kJ} \mathrm{~mol}^{-1}$ determined by DSC. ${ }^{15}$ The $\mathrm{Pt}-\mathrm{Me}$ bond is slightly stronger. ${ }^{17}$

For comparison, a DSC study of the thermolysis of $\left[\mathrm{PtIMe}_{3}\right.$ (bpy)] was carried out (Figure 3). Decomposition occurred giving an exotherm over the region $240-300^{\circ} \mathrm{C}$, with a peak at $273 \pm 2^{\circ} \mathrm{C}$. However, the weight loss was $11 \%$, compared to the theoretical value of $5.7 \%$ for loss of ethane, and the major product was methane. Clearly, this is not a simple reductive elimination reaction, and so the $\mathrm{Pt}-\mathrm{Me}$ bond energy could not be determined. The difference in thermal stabilities of the precursors $\left[\mathrm{MMe}_{2}(\mathrm{bpy})\right](\mathrm{M}=\mathrm{Pd}$ or $\mathrm{Pt})$ is much less as shown in Figure 4, though decomposition of the palladium complex is more exothermic.

\section{Conclusions}

Both the oxidative addition and reductive elimination studied in this work appear to involve the intermediacy of the solvated cation $\left[\mathrm{PdMe}_{3}(\mathrm{bpy})\right]^{+}$, at least to a major extent in solution reactions. The reductive elimination of ethane is intramolecular, and we note that the apparent activation energy $E_{\text {a }}$ for reductive elimination in acetone or methanol is much lower $\left(E_{\mathrm{a}}\right.$ values $65 \mathrm{~kJ} \mathrm{~mol}^{-1}$ in ace-

(16) It is important to note that, although the thermochemical date for the solid state are precise, the correction to the gas phase depends on assumptions that cannot be verified. Hence the error limits to $E$ (PdC) are minimum values. Mortimer, C. T. McNaughton, J. L.; Puddephatt, R. J. J. Chem. Soc., Dalton Trans. 1972, 1265 and references therein. (17) In the isostructural Pd(IV) and Pt(IV) complexes [MMe $\mathrm{M}_{3}$ itris(pyrazol-1-yl)methanel]I, the $\mathrm{Pd}-\mathrm{C}$ and $\mathrm{Pt}-\mathrm{C}$ bond lenoths are similar, and in the complexes cis-[MMe $\left.\left(\mathrm{PMePh}_{2}\right)_{2}\right]$, the $\mathrm{M}-\mathrm{C}$ bond is slightly shorter and the $\mathrm{M}-\mathrm{P}$ bond slightly longer when $\mathrm{M}=\mathrm{Pd}$ compared to when $\mathrm{M}=$ Pt. Again this supports a strong $\mathrm{Pd}-\mathrm{C}$ bond. Wisner, J. M.; Bartczak, T. J.; Ibers, J. A. Organometallics 1985, 5, 2044.

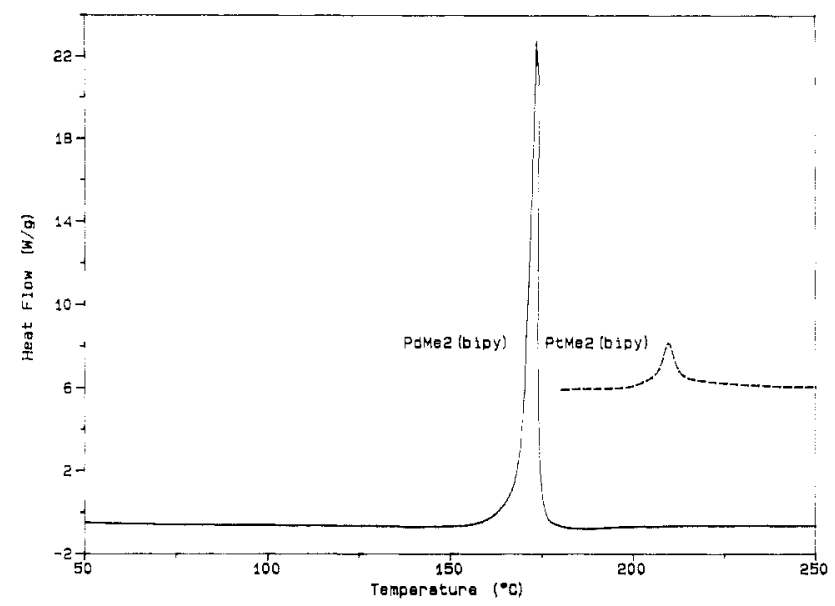

Figure 4. Differential scanning calorimetry for the decomposition of (a) $\left[\mathrm{PdMe}_{2}(\mathrm{bpy})\right]$ and (b) $\left[\mathrm{PtMe}_{2}(\mathrm{bpy})\right]$.

tone, $78 \mathrm{~kJ} \mathrm{~mol}^{-1}$ in acetone with excess $\mathrm{I}^{-}, 39 \mathrm{~kJ} \mathrm{~mol}^{-1}$ in methanol with excess $\mathrm{I}^{-}$) than the estimated Pd-Me bond energy of $\sim 130 \mathrm{~kJ} \mathrm{~mol}^{-1}$. Although iodide dissociation is implicated in the reductive elimination, this step is unlikely to affect the Pd-Me bond energy significantly. ${ }^{18}$ Hence the actual reductive elimination must be a concerted process and could occur in a similar way to that proposed earlier for reductive elimination from platinum(IV) (eq 5)..$^{15}$

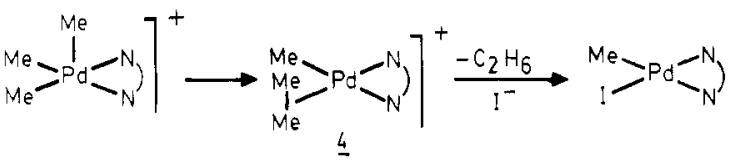

However, in view of the more recent evidence that $\alpha$ elimination can occur readily and reversibly from coordinatively unsaturated metal alkyl derivatives ${ }^{19}$ and that $\mathrm{C}-\mathrm{C}$ bond activation in both homogeneous and heterogeneous conditions may necessarily occur after $\mathrm{C}-\mathrm{H}$ activation, ${ }^{19,20}$ an alternative mechanism should also be considered (eq 6).

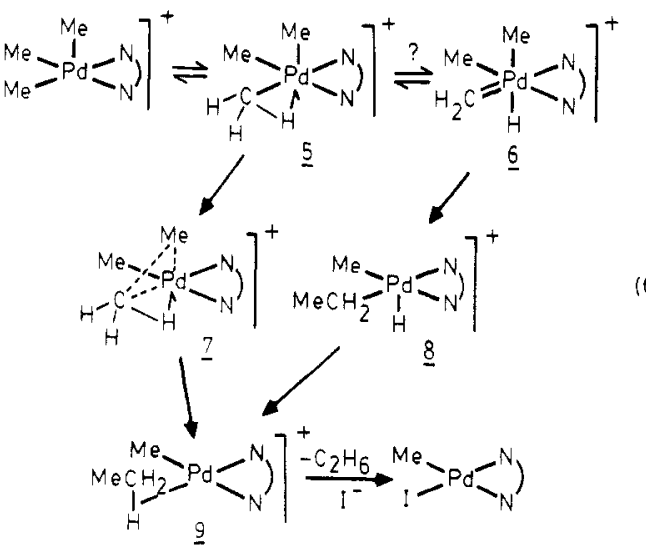

Migration of a methyl to a methylene group is well-established, ${ }^{2}$ and the mechanism accounts in a rational way for the need for a vacant coordination site prior to reductive elimination. Either mechanism of eq 5 or eq 6

(18) Although other factors are present, it is of interest to note here that the iodide salt of the closely related cation IPdMe 3 itris(pyridin-2 yl)methane\}] ${ }^{+}$is more stable than [PdIMe [ $\left._{3}(\mathrm{bpy})\right]$ both in the solid state and in chloroform solution. ${ }^{9}$ (19)

(19) Brookhart, M.; Green, M. L. H. J. Organomet. Chem. 1983, 250,

(20) Periana, R. A.; Bergman, R. G. J. Am. Chem. Soc. 1984, 106, 7272 For activation of ethane at a Pt surface, see: Parshall, G. W. Homogeneous Catalysis; Wiley: New York, 1980; p 181 
appears to be consistent with the experimental data reported here. We note that, in eq $6, \alpha$-elimination to give 6 need not occur prior to $\mathrm{C}-\mathrm{C}$ bond formation since the agostic interaction ${ }^{19}$ in 5 involves a rocking motion which will facilitate (and could be concurrent with) $\mathrm{C}-\mathrm{C}$ bond formation, as shown in 7. ${ }^{21}$ Steric hindrance to $\mathrm{C}-\mathrm{C}$ bond formation should therefore be less than in complex 4 of eq 5 . Intermediate $\mathbf{7}$ is favored over 8 since the latter could reductively eliminate methane or ethane or $\beta$-eliminate ethylene and so would not be expected to give the high observed selectivity for formation of ethane. ${ }^{21}$

The rates of reaction and the activation parameters for oxidative addition of $\mathrm{MeI}$ to $\left[\mathrm{PdMe}_{2}\right.$ (bpy)] and [ $\mathrm{PtMe}_{2}$ (bpy)] are similar, with the platinum complex being the more reactive. The mechanisms are clearly the same, namely, the $\mathrm{S}_{\mathrm{N}} 2$ mechanism, for both systems. However, reductive elimination of ethane occurs easily for [PdIMe ${ }_{3}($ bpy) $]$ but does not occur at all for $\left[\mathrm{PtIMe}_{3}(\mathrm{bpy})\right]$. This major difference in reactivity is not due to a large difference in $\mathrm{M}-\mathrm{Me}$ bond energies in the two complexes but is due to a much lower activation energy for concerted reductive elimination for the palladium complex..$^{22}$ The platinum(IV) complex forms stable complexes [ $\mathrm{PtMe}_{3}$ (bpy)S $]^{+}(\mathrm{S}=$ acetone or $\mathrm{MeCN})$ which do not reductively eliminate ethane whereas the analogous palladium cations do so very readily.

We note that the above oxidative addition-reductive elimination reactions provide a good model for catalytic C-C coupling reactions via the $\mathrm{Pd}(\mathrm{II})-\mathrm{Pd}(\mathrm{IV})$ cycle. ${ }^{4-7}$ However, since the diimine ligands used here favor Pd(IV) whereas the phosphine ligands used in the catalytic reactions favor $\operatorname{Pd}(0)$, caution should be exercised in extrapolation to the catalytic reactions. Nevertheless, if the $\mathrm{Pd}(\mathrm{II})-\mathrm{Pd}(\mathrm{IV})$ cycle is correct, the detailed mechanisms of the oxidative addition and reductive elimination steps may be similar to those established in this work.

\section{Experimental Section}

${ }^{1} \mathrm{H}$ NMR spectra were recorded by using a Bruker AM-300 spectrometer, and kinetic studies were carried out by using a

(21) The difficulty of direct $\mathrm{C}-\mathrm{C}$, compared to $\mathrm{C}-\mathrm{H}$ or $\mathrm{H}-\mathrm{H}$, reductive elimination has been rationalized by theoretical studies. In particular, high level GVB calculations of the transition state for reductive elimination of ethane from $\mathrm{PdMe}_{2}$ or $\mathrm{PtMe}_{2}$ predict that the methyl groups should be tilted by $39^{\circ}$ and $51^{\circ}$, respectively, leading to a geometry similar to that in the classic agostic $\mathrm{TiCH}_{3}$ unit. 19 Thus, although the agostic $\mathrm{PdCH}_{3}$ interaction was not explicitly discussed, it is implicitly predicted by the GVB calculations. Low, J. J.; Goddard, W. A. Organometallics 1986, 5, 609. Low, J. J.; Goddard, W. A. J. Am. Chem. Soc. 1986, 108, 6115 .

(22) GVB calculations on $\mathrm{MCl}_{2} \mathrm{Me}_{2}\left(\mathrm{PH}_{3}\right)_{2}$ predict similar intrinsic M-Me bond energies of 51 and $52 \mathrm{kcal} \mathrm{mol}^{-1}$ but significantly different average adiabatic bond energies of 31.7 and $10.0 \mathrm{kcal} \mathrm{mol}^{-1}$, when $\mathrm{M}=$ $\mathrm{Pt}$ and $\mathrm{Pd}$, respectively. The activation energies for reductive elimination were calculated to be $34.9 \mathrm{kcal} \mathrm{mol}^{-1}$ and zero for $\mathrm{M}=\mathrm{Pt}$ and $\mathrm{Pd}$, respectively. ${ }^{21}$
Varian CARY 2290 spectrometer, with temperature control using a Polyscience Series 900 constant temperature bath. Differential scanning calorimetry was carried out by using a Du Pont Instruments 912 DSC in conjunction with the 9900 computer/ thermal analyzer. All samples were run in uncrimped, closed Al pans under $\mathrm{N}_{2}$ atmosphere, purging at $20 \mathrm{~mL} \mathrm{~min}{ }^{-1}$. The scan rate was $20^{\circ} \mathrm{C} \mathrm{min}^{-1}$, and calibration was with In metal. The error limits given are standard deviations from six independent runs.

$\left[\mathrm{PdMe}_{2}(\mathrm{bpy})\right]$ and $\left[\mathrm{PdIMe}_{3}(\mathrm{bpy})\right]$ were prepared by the reported method.,10

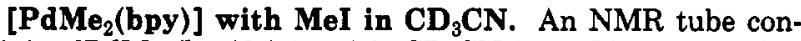
taining [PdMe $\left(\right.$ bpy)] $(10 \mathrm{mg})$ in $\mathrm{CD}_{3} \mathrm{CN}(0.5 \mathrm{~mL})$ was cooled to $-45^{\circ} \mathrm{C}$, and MeI $(6 \mu \mathrm{L})$ was added. The ${ }^{1} \mathrm{H}$ NMR spectrum at $-40^{\circ} \mathrm{C}$ contained resonances due to fac-[PdIMe $\left.{ }_{3}(\mathrm{bpy})\right], \delta 1.79(\mathrm{~s}$, $2 \mathrm{Me}, \mathrm{Me}$ trans to $\mathrm{N}$ ) and 1.20 (s, I Me, Me trans to I), and additional peaks assigned to fac- $\left[\mathrm{PdMe}_{3}\left(\mathrm{CD}_{3} \mathrm{CN}\right)(\mathrm{bpy})\right]^{+}, \delta 1.61$ (s, $2 \mathrm{Me}, \mathrm{Me}$ trans to bpy) and 1.06 (s, $1 \mathrm{Me}, \mathrm{Me}$ trans to $\mathrm{CD}_{3} \mathrm{CN}$ ). Further details are given in the text.

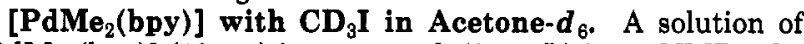
$\left[\mathrm{PdMe}_{2}(\mathrm{bpy})\right](10 \mathrm{mg})$ in acetone- $d_{6}(0.5 \mathrm{~mL})$ in an NMR tube was cooled to $-60^{\circ} \mathrm{C}$, and $\mathrm{CD}_{3} \mathrm{I}(6 \mu \mathrm{L})$ was added. At $-60^{\circ} \mathrm{C}$, the ${ }^{1} \mathrm{H} N M R$ spectrum contained resonances due to [PdMe $\left.(\mathrm{bpy})\right]$ and $\left[\mathrm{PdIMe}_{2}\left(\mathrm{CD}_{3}\right)(\mathrm{bpy})\right]$, but no ionic intermediate was detected. The resonances due to $\left[\mathrm{PdIMe}_{2}\left(\mathrm{CD}_{3}\right)(\mathrm{bpy})\right]$ gave the ratio $\mathrm{Me}$ trans to $\mathrm{N}: \mathrm{Me}$ trans to $\mathrm{I}=2: 1$, showing that the oxidative addition was not stereospecific.

Kinetic Studies of Oxidative Addition by UV-Visible Spectrophotometry. A solution of [PdMe $\left.\mathrm{Pd}_{2}(\mathrm{bpy})\right]$ in acetone ( 3 $\mathrm{mL}, 3 \times 10^{-4} \mathrm{M}$ ) in a cuvette was thermostated at $20.0^{\circ} \mathrm{C}$, and a known excess of $\mathrm{MeI}$ was added by using a microsyringe. After rapid stirring, absorbance values at $\lambda=440 \mathrm{~nm}$ were collected at 0.1 -min intervals for $10 \mathrm{~min}$, at which time reaction was complete. Computer treatment of the data showed good first-order kinetics from which the observed first-order rate constants and standard deviations were obtained. A plot of $k_{\text {obed }}$ vs [MeI] was linear, and the slope gave the second-order rate constant. The same method was used at other temperatures, and the activation parameters were obtained from the Arrhenius equation.

The oxidative addition to $\left[\mathrm{PtMe}_{2}(\mathrm{bpy})\right]$ was monitored in a similar way but with $\lambda=452 \mathrm{~nm}$.

Kinetic Studies of Reductive Elimination by UV-Visible Spectrophotometry. A freshly prepared solution of $\left[\mathrm{PdIMe}_{3}-\right.$ (bpy)] (purified and stored in the dark at $-20^{\circ} \mathrm{C}$ ) in acetone $(3$ $\mathrm{mL}, 3 \times 10^{-4} \mathrm{M}$ ) was transferred to a cuvette and thermostated to $20.0^{\circ} \mathrm{C}$ in the cell compartment of the spectrophotometer. Absorbance values at $\lambda=380 \mathrm{~nm}$ were collected at $0.2-\mathrm{min}$ intervals for $1 \mathrm{~h}$. Computer treatment showed good first-order kinetics from which the first-order rate constant and standard deviation were calculated. The same method was used to determine rate constants at higher temperatures, and activation parameters were determined from the Arrhenius equation.

The same method was used to collect data in benzene or methanol solvents and in the presence of additives.

Acknowledgment. We thank the ARGS (Australia) and NSERC (Canada) for financial support.

Registry No. 1, 95841-49-9; fac-2, 110182-93-9; fac-[PdMe ${ }_{3}$ $\left(\mathrm{CD}_{3} \mathrm{CN}\right)($ bpy $\left.)\right]^{+}, 113748-25-7$; [PdIMe $3\left(\mathrm{CD}_{3}\right)($ bpy)], 113748-26-8; [PtMe 2 (bpy)], 52594-52-2. 